\title{
COMPUTER MODELLING OF RC BEAMS REINFORCED WITH HIGH STRENGTH REBARS AND STEEL PLATE
}

doi: 10.2478/cqpi-2019-0041

Date of submission of the article to the Editor: 08/03/2019

Date of acceptance of the article by the Editor: 20/05/2019

Taras Bobalo ${ }^{1}$ - orcid id: 0000-0001-9581-5533

Yaroslav Blikharskyy ${ }^{2}$ - orcid id: 0000-0002-3374-9195

Pavlo Krainskyi ${ }^{1}$ - orcid id: 0000-0003-3253-6726

Myhailo Volynets ${ }^{1}$ - orcid id: 0000-0003-3166-8356

${ }^{1}$ Lviv Polytechnic National University, Department of Building Constructions and Bridges, 6 Karpinskogo Street, 79013, Lviv, Ukraine

${ }^{2}$ Lviv Polytechnic National University, Department of Highways and Bridges, 6 Karpinskogo Street, 79013, Lviv, Ukraine

Abstract: The use of computers provides the opportunity to analyse and design complex structures, taking into account the geometric and physical nonlinearity of construction materials. In the article the study of stress-strain state of mixed steelconcrete beams, were presented. The results of this study showed that the method of calculation according to designe codes gave satisfactorily results of calculated strength compared with experiments. However, these methodes do not provide complete information of structural performance at all levels of load. For a more complete study of the stress-strain state and the physical nature of the processes occurring in steel-concrete structures reinforced with a mixed reinforcement, the calculation method using "Lira" software complex is proposed. The method of calculation is based on the finite element method. The calculation is made taking into account physical nonlinearity and real diagrams of $\sigma-\varepsilon$ of materials using the nonlinear deformation law №14 of "Lira" software complex. The proposed method of calculation allows to determine the values of bearing capacity, the development of deformations and the beginning of crack formation, as well as stresses at all load levels.

Keywords: load-carrying ability, deformability, mixed reinforcement, high-strength rebar, external reinforcement.

\section{INTRODUCTION}

Nowadays, reinforced concrete is one of the most common material used in construction. Since reinforced concrete is a composite material that combines the joint work of concrete and steel rebar, there is a questions of the most effective design solution for the efficient rebar placement and optimal rebar steel grade combination to ensure the economy and reliability of structures (Zhang et al., 2015; Blikhars'kyi and Obukh, 2018; Dudek et al. 2017; Selejdak et al. 2014). To date, many research have been conducted in the field of concrete mechanical properties improvement (Al Saffar 
et al., 2019; Fadhil et al., 2018; Sobol et al., 2014; Tayeh, et al., 2013; Abu-Tair, et al., 1996). Low reliability and insufficient bearing capacity of reinforced concrete structures is often a result of faults in manufacturing process and design (Koz, et al. 2017; Selejdak, et al., 2018), increased seismic resistance requirements (Alghuff, et al., 2019; Kramarchuk, et al., 2018) causing the need in strengthening or structural retrofitting (Blikharskyy et al. 2019; Blikharskyy, 2018; Brozda et al 2018; Khmil, et al., 2018; Krainskyi et al., 2018; Vegera, et al., 2018). Therefore, all these problems need to be taken into account in the design of reinforced concrete structures.

It is a common practice to carry out an experimental study of the newly designed structures before mass production. This ensures confidence in the reliability of the design and the compliance with the calculations. But during field experiments, there is always an issue of errors coming from slight deviations from the design. The presence of such inaccuracies makes it impossible to obtain clear and $100 \%$ correct results in analysis of the stressed state of various structures with combined reinforcement, which incorporate the combined work of concrete and reinforcement of several steel grades with significantly different modulus of elasticity. Therefore, the main task of this study is to develop a calculation model using the software complex "Lira" and compare the results obtained through simulation with the results of real laboratory testing. A broad modeling of steel concrete structures with combined reinforcement is planned after this comparison in order to provide recommendations on the optimal percentage of reinforcement of reinforced concrete structures with combined reinforcement.

Laboratory testing of structures with combined reinforcement (Bobalo et al., 2018) showed that the main difference from common reinforced concrete structures is the presence of residual strength after yielding in the lower grade reinforcement. The structure does not collapse immediately but shows the ductile behavior and continues to carry the load up to yielding in high-grade rebar.

Performance of flexural elements with combined reinforcement have been determined in previous studies (Bobalo et al., 2018). The further aim is to study the influence of the percentage of high-grade reinforcement without prestress on the strength and deformability of the structure, and to provide recommendations for optimal design of steel-concrete beams with combined high-grade rebar and external plate reinforcement.

\section{RESEARCH METHODOLOGY}

The correct calculation of structures depends on the accuracy of the input information on the physical and mechanical properties of materials. Therefore the real stressstrain diagrams " $\sigma-\varepsilon$ " of materials were used when creating a calculation model.

A 2D model of the beam was split into rectangular and linear finite elements. The linear element that represents steel rebar is subjected to axial tension or compression only, and accordingly has four degrees of freedom. The rectangular element that represents concrete, is in a flat stressed state and has eight degrees of freedom.

Each node has two possible translations - $\mathrm{x} i \mathrm{z}$. The $\mathrm{i}$-th linear finite element is represented by the coordinates of two points $(1,2)$, has a linear length $L$, and the dimensions of the cross section are $\mathrm{B}, \mathrm{H}$. The parameters of the material are described using the law of nonlinear deformation of material No. 14 (PC "Lira"), based on real nonlinear stress-strain diagrams of steel. 
The linear element works only in tension and compression. It does not have any flexural deformations. The flat finite element is represented by the coordinates of the four nodes $(1,2,3,4)$, the area $S$ and the thickness $H$. Parameters of the material are described similarly, using the law of nonlinear deformation of material No. 14 (PC "Lear"), based on real nonlinear stress-strain diagram of concrete.

Finite element model is presented in Fig. 1.

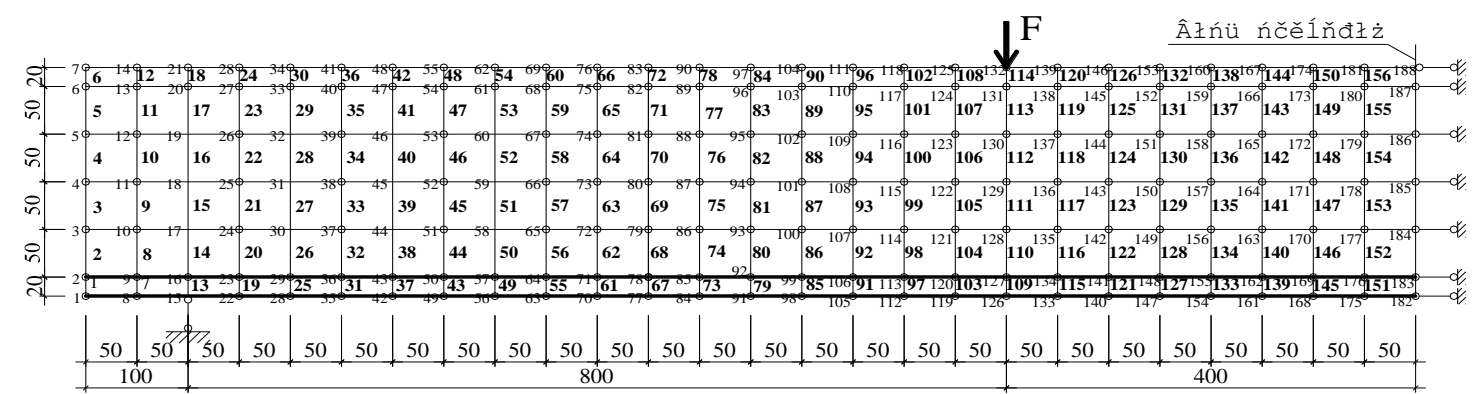

Fig. 1. Finite element model of the beam

In the calculation model, the loading of the reinforced concrete element with combined reinforcement was applied incrementally, adding $10 \%$ of the failure load at each increment. The load increments corresponded to laboratory tests performed earlier (Bobalo et al., 2018). According to the analysis results for each stage of the load, the received stresses and strain data were compared with laboratory tests.

Laboratory tests consisted of eight reinforced concrete beams with a cross section of $0.12 \times 0.24 \mathrm{~m}$, with a $2.4 \mathrm{~m}$ span. Outer plate reinforcement was connected to the beam with U-shaped anchors welded to the plate.

Reinforcement details of test beams are shown on Fig. 2.
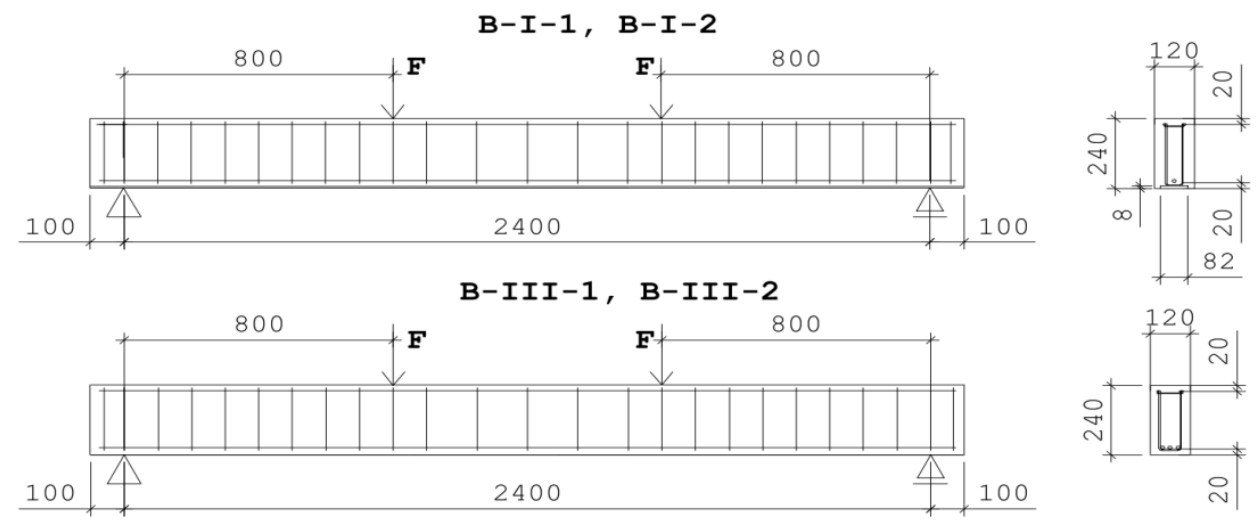

Fig. 2. Reinforcement details of test beams

In order to reduce the absolute error during laboratory testing, duplicate "twin" beams were tested. All samples were made from one concrete mix. This approach allowed us to obtain accurate experimental results (Bobalo et al., 2018). 
Table 1.

Physical and mechanical properties of materials of the experimental beams

\begin{tabular}{|c|c|c|c|c|c|}
\hline \multicolumn{2}{|c|}{ Notation of the beams } & $\begin{array}{l}\text { B - I-1, } \\
\text { B - I - } 2\end{array}$ & $\begin{array}{l}\text { B - II - 1, } \\
\text { B - II - } 2\end{array}$ & $\begin{array}{l}\text { B - III - 1, } \\
\text { B - III - } 2\end{array}$ & $\begin{array}{l}\text { B - IV - 1, } \\
\text { B - IV - } 2\end{array}$ \\
\hline \multirow{3}{*}{ Concrete } & $\begin{array}{c}\text { ck,cube } / f \text { ck,prism, } \\
\mathrm{MPa}\end{array}$ & $\begin{array}{c}48,7 / \\
29,6\end{array}$ & $\begin{array}{c}46,3 / \\
28,1\end{array}$ & $\begin{array}{c}46,3 / \\
28,1\end{array}$ & $\begin{array}{c}49,2 / \\
29,9\end{array}$ \\
\hline & $\mathrm{f}_{\mathrm{cd}}, \mathrm{MPa}$ & 22,8 & 21,6 & 21,6 & 23,0 \\
\hline & $\mathrm{E}_{\mathrm{cm}} \times 10^{3}, \mathrm{MPa}$ & 38,00 & 37,76 & 38,04 & 38,50 \\
\hline \multirow{5}{*}{$\begin{array}{l}\text { Reinforcement of the } \\
\text { tension zone - } \\
\text { longitudinal plate }\end{array}$} & $\mathrm{B}_{\mathrm{s}} \times \mathrm{t}_{\mathrm{s}}, \mathrm{mm}$ & $82 \times 8$ & $46 \times 8$ & - & $114 \times 8$ \\
\hline & $f_{y k}, M P a$ & 287 & 287 & - & 287 \\
\hline & $f_{y d}, M P a$ & 273 & 273 & - & 273 \\
\hline & $\mathrm{E}_{\mathrm{p}} \times 10^{5}, \mathrm{MPa}$ & 2,05 & 2,05 & - & 2,05 \\
\hline & Grade & $\mathrm{C} 275$ & $\mathrm{C} 275$ & - & $\mathrm{C} 275$ \\
\hline \multirow{5}{*}{$\begin{array}{l}\text { Reinforcement of the } \\
\text { tension zone - } \\
\text { longitudinal bar }\end{array}$} & $\varnothing, \mathrm{mm}$ & $1 \varnothing 10$ & $2 ø 10$ & $3 ø 10$ & - \\
\hline & $f_{y k}, M P a$ & 1080 & 1080 & 1080 & - \\
\hline & $\mathrm{f}_{\mathrm{yd}}, \mathrm{MPa}$ & 900 & 900 & 900 & - \\
\hline & $\mathrm{E}_{\mathrm{p} \times 10^{5}, \mathrm{MPa}}$ & 1,85 & 1,85 & 1,85 & - \\
\hline & Grade & A1000 & A1000 & A1000 & - \\
\hline \multirow{5}{*}{$\begin{array}{l}\text { Reinforcement of the } \\
\text { compression zone - } \\
\text { longitudinal bar }\end{array}$} & $\varnothing, \mathrm{mm}$ & 8 & 8 & 8 & 8 \\
\hline & $f_{y k}{ }^{\prime}, M P a$ & 594,5 & 594,5 & 594,5 & 594,5 \\
\hline & $\mathrm{f}_{\mathrm{yd}} \mathrm{d}^{\prime}, \mathrm{MPa}$ & 495 & 495 & 495 & 495 \\
\hline & $\mathrm{E}_{\mathrm{p}}{ }^{\prime} \times 10^{5}, \mathrm{MPa}$ & 2,05 & 2,05 & 2,05 & 2,05 \\
\hline & Grade & A400C & A400C & A400C & A400C \\
\hline \multirow{4}{*}{ Ties - transverse bars } & $\varnothing, \mathrm{mm}$ & 5 & 5 & 5 & 5 \\
\hline & $\mathrm{f}_{\mathrm{ywd}}, \mathrm{MPa}$ & 296 & 296 & 296 & 296 \\
\hline & $\mathrm{E}_{\mathrm{p} \times 10^{5}, \mathrm{MPa}}$ & 2,05 & 2,05 & 2,05 & 2,05 \\
\hline & Grade & A240C & A240C & A240C & A240C \\
\hline
\end{tabular}

\section{RESULTS OF THE ANALYSIS AND THE EXPERIMENTAL STUDY}

Finite element modeling and analysis allowed us to obtain the values of stresses and strain in concrete and reinforcement, at all stages of loading until failure.

The result of analysis obtained on the basis of finite element modeling using PC "Lira" considering physical nonlinearity and real diagrams of $\sigma-\varepsilon$ of materials for the beam B-III is shown on Fig.3.

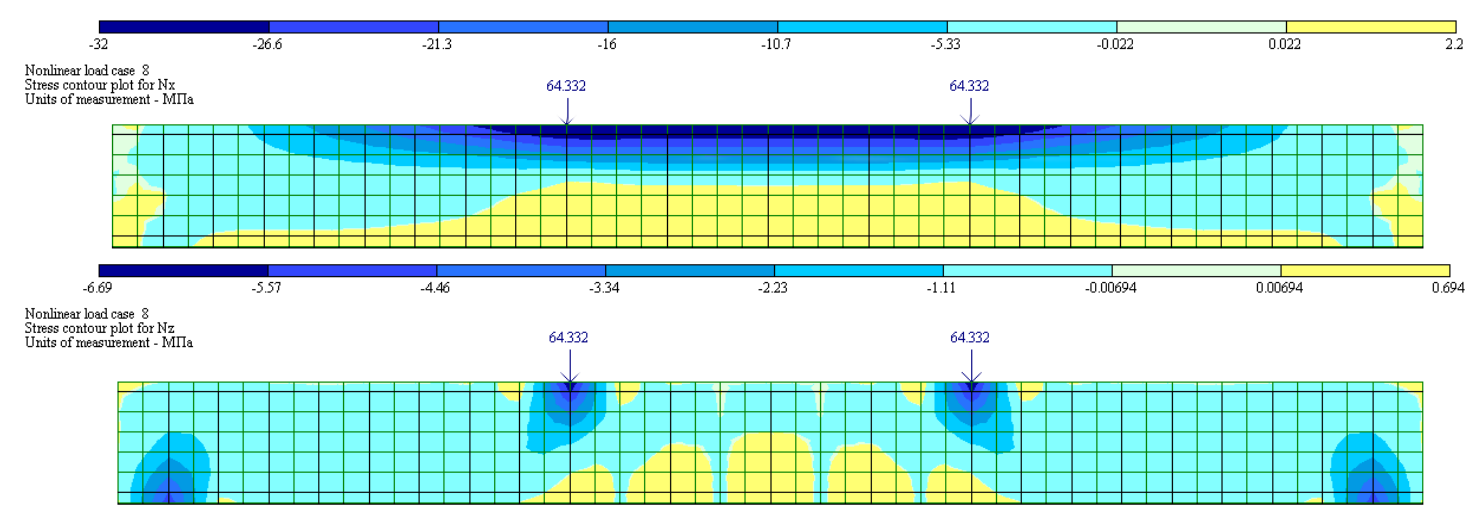

Fig. 3. Estimated stresses in beam B-III at failure load

Comparison of the results of computer calculations and experimental laboratory studies (Bobalo et al., 2018) is presented in Table 2. 
Table 2.

Comparison of the numerical code verification, FE analysis and laboratory tests of reinforced concrete beams with combined reinforcement

\begin{tabular}{|c|c|c|c|c|c|c|c|c|}
\hline \multirow[b]{2}{*}{$\begin{array}{l}\text { Notation of } \\
\text { the beams }\end{array}$} & \multirow{2}{*}{ 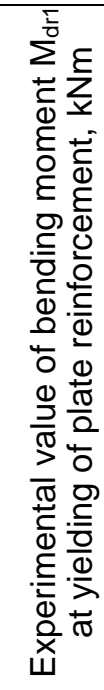 } & \multirow{2}{*}{ 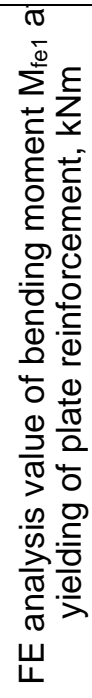 } & \multirow[b]{2}{*}{ 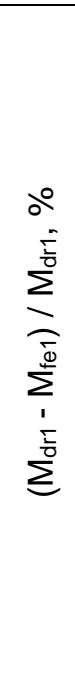 } & \multicolumn{5}{|c|}{$\begin{array}{l}\text { Bearing capacity (high-grade rebar yielding, } \\
\text { concrete crushing) }\end{array}$} \\
\hline & & & & 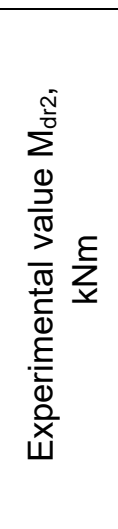 & 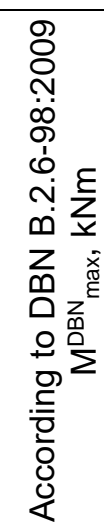 & 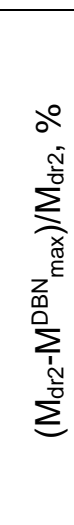 & 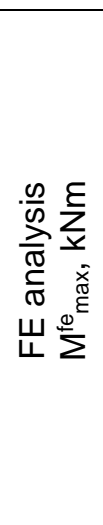 & 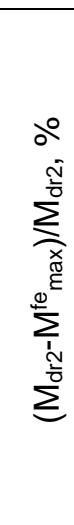 \\
\hline$B-I-1$ & 42,70 & \multirow{2}{*}{43.5} & -1.9 & 51,52 & \multirow{2}{*}{51,38} & 0,3 & \multirow{2}{*}{51,4} & 0,2 \\
\hline B-I- 2 & 43,60 & & 0.2 & 52,64 & & 2,4 & & 2,4 \\
\hline B - II - 1 & 31,10 & \multirow{2}{*}{30.1} & 3,2 & 55,20 & \multirow{2}{*}{52,10} & 5,6 & \multirow{2}{*}{52,3} & 5,3 \\
\hline B - II - 2 & 31,10 & & 3,2 & 52,40 & & 0,6 & & 0,2 \\
\hline B - III - 1 & - & & - & 55,36 & \multirow{2}{*}{52,85} & 4,5 & \multirow{2}{*}{53,7} & 3,0 \\
\hline B - III - 2 & - & & - & 57,04 & & 7,3 & & 5,9 \\
\hline$B-I V-1$ & 51,49 & \multirow{2}{*}{50.4} & 2.1 & 51,49 & \multirow{2}{*}{50,25} & 2,4 & \multirow{2}{*}{50,4} & 2,1 \\
\hline B - IV - 2 & 50,57 & & 0.3 & 50,57 & & 0,6 & & 0,3 \\
\hline
\end{tabular}

The obtained results of finite element analysis corresponds to the experimental data with sufficient accuracy. This confirms the possibility of using the such models for calculations of reinforced concrete structures with combined outer plate reinforcement and internal high-grade rebar.

The deviation of the results of the bearing capacity of beams according to finit element analysis does not exceed the experimental data more than 5.9\% (Table 2).

Computer calculation using the software complex "Lira", based on finite element method, considering the real stress-strain diagrams " $\sigma-\varepsilon$ " of materials, corresponds to the performance of a real reinforced concrete structures with combined reinforcement. This proves that the proposed design model allows to estimate the load bearing capacity, deformations, stress in the rebar and outer plate reinforcement with sufficient accuracy.

\section{CONCLUSIONS}

The implemented computer calculation program (based on finite element methods and successive approximations, considering real stress-strain diagrams of materials) corresponds to the performance of a real reinforced concrete structures with combined reinforcement.

The proposed method allows to carry out modeling and analysis of the behavior of reinforced concrete structures with sufficient accuracy. Also it is possible to compare 
unlimited number of design solutions with the same characteristics of materials, which allows to study different patterns of the work of reinforced concrete structures.

The proposed program allows to obtain a real distribution of stresses and strain not only in concrete, but also in longitudinal and transverse reinforcement at all stages of loading.

\section{References}

Abu-Tair, A., Rigden, S., Burley, E., 1996. Testing the Bond Between Repair Materials and Concrete Substrate, ACI Materials Journal, 93(6), 553-558

Tayeh, B., Bakar, B.H., Megat J., Megat A., Voo, Y. 2013. Evaluation of Bond Strength between Normal Concrete Substrate and Ultra High Performance Fiber Concrete as a Repair Material, Procedia Engineering, 54, 554-563. 10.1016/j.proeng.2013.03.050.

Alghuff, A., Shihada, S., Tayeh, B., 2019. Comparative Study of Static and Response Spectrum Methods for Seismic Analysis of Regular RC Buildings, Journal of Applied Sciences.

Al Saffar, D., Alsaad, A., Tayeh, B. 2019. Effect of Internal Curing on Behavior of High Performance Concrete: An Overview. Case Studies in Construction Materials, 10. 10.1016/j.cscm.2019.e00229.

Blikhars'kyi, Z. Ya., Obukh, Y. (2018). Influence of the Mechanical and Corrosion Defects on the Strength of Thermally Hardened Reinforcement of 35GS Steel. Materials Science, 54. 10.1007/s11003-018-0183-2.

Blikharskyy, Y., Khmil, R., Blikharskyy, Z., 2018. Research of RC Columns Strengthened by Carbon FRP Under Loading, Matec Web of Conferences, 174, 18, DOI: 10.1051/matecconf/201817404017

Blikharskyy, Z., Selejdak, J., Blikharskyy, Y., Khmil, Roman., 2019. Corrosion of Reinforce Bars in RC Constructions, System Safety: Human - Technical Facility Environment. 1. 277-283. 10.2478/czoto-2019-0036.

Bobalo, T., Blikharskyy, Y., Vashkevich, R., Volynets, M., 2018. Bearing capacity of $R C$ beams reinforced with high strength rebars and steel plate. Matec Web of Conferences, 230, 02003, DOI: 10.1051/matecconf/201823002003.

Brózda, K., Selejdak, J., Koteš, P., 2017. The Analysis of Beam Reinforced with FRP Bars in Bending, Procedia Engineering, 192, 64-68, DOI: 10.1016/j.proeng.2017.06.011

Dudek, A., Lisiecka, B., Ulewicz, R., 2017. The Effect of Alloying Method on the Structure and Properties of Sintered Stainless Steel, Archives of Metallurgy and Materials, 62(1), 281-287, DOI: 10.1515/amm-2017-0042

Fadhil, B., Al-Rumaithi, A., Al-Sherrawi, M. 2018. Properties of Reactive Powder Concrete with Different Types of Cement. International Journal of Civil Engineering and Technology. 9. 1313-1321.

Khmil, R., Tytarenko R., Blikharskyy, Y., Vegera, P., 2018. Development of the procedure for the estimation of reliability of reinforced concrete beams, strengthened by building up the stretched reinforcing bars under load, EasternEuropean Journal of Enterprise Technologies, 5/7 (95), DOI: 10.15587/17294061.2018.142750.

Kos Ž., Gotal Dmitrović, L., Klimenko, E., 2017. Developing a Model of a Strain (Deformation) of a Damaged Reinforced Concrete Pillar in Relation to a Linear Load Capacity, Technical Journal, 11(4), 150-154, (https://hrcak.srce.hr/190990) 
Krainskyi, P., Blikharskyy, Y., Khmil, R., Blikharskyy, Z., 2018. Experimental Study of the Srengthening Effect of Reinforced Concrete Columns Jacketed Under Service Load Level, Matec Web of Conferences, 183, 1-5, DOI: 10.1051/matecconf/201818302008

Krainskyi, P., Blikharskyy, Y., Khmil, R., Vegera, P., 2018. Influence of loading level on the bearing capacity of $R C$ columns strengthened by jacketing. Matec Web of Conferences, 230, 02013, DOI: 10.1051/matecconf/201823002013.

Kramarchuk, A., Ilnytskyy, B., Lytvyniak, O., Grabowski, A., 2019. The increase of seismic stability for existing industrial buildings. AIP Conference Proceedings. 2077. 020029. 10.1063/1.5091890.

Selejdak, J., Khmil R., Blikharskyy, Z., 2018. The Influence of Simultaneous Action of the Aggressive Environment and Loading on Strength of RC Beams, Matec Web of Conference, 183, 1-6, DOI: 10.1051/matecconf/201818302002

Selejdak, J., Ulewicz, R., Ingaldi, M., 2014. The Evaluation of the Use of a Device for Producing Metal Elements Applied in Civil Engineering, $23^{\text {rd }}$ International Conference on Metallurgy and Materials, Ostrava, Tanger, 1882-1888

Sobol, K., Blikharskyy, Z., Petrovska, N., Terly`a, V., 2014. Analysis of Structure Formation Peculiarities during Hydration of Oil-Well Cement with Zeolitic Tuff and Metakaolin Additives, Chemistry \& Chemical Technology 8(4), 461-465 DOI: 10.23939/chcht08.04.461

Vegera, P., Vashkevych, R., Blikharskyy, Z., 2018. Fracture Toughness of RC Beams With Different Shear Span, Matec Web of Conferences, 174, 1-8, DOI: 10.1051/matecconf/201817402021

Yang, M., Zhou, J., Zhang, H., Liao, L., Zhao, R., 2018. Magnetic Memory Detection of Rebar Corrosion in Concrete, Journal of Building Materials. 21. 345-350. DOI: 10.3969/j.issn.1007-9629.2018.02.028.

Zhang, Q., Mol'kov, Y.V., Sobko, Y.M., Blikhars'kyi, Y.Z., Khmil, R.E., 2015. Specific Fracture Energy of Thermally Hardened Reinforcement, Materials Science, 50(6), 824-829. 